\title{
Pengaruh Model Pembelajaran dan Gaya Belajar terhadap Keterampilan Berpikir Kritis Peserta Didik Kelas XI IPA SMA Negeri 3 Palopo Pada Materi Pokok Larutan Asam Basa
}

\section{The Influence of Instructional Model and Learning Style to Critical Thinking Skills of Students in Class XI Science SMAN 3 Palopo in The Subject Matter Acid-Base Solution}

\author{
Nurasia \\ Jurusan Kimia Fakultas Sains \\ Universitas Cokroaminoto Palopo \\ Email: Nurasia.Kimia@yahoo.com
}

\begin{abstract}
ABSTRAK
Penelitian ini bertujuan untuk mengetahui pengaruh dari model pembelajaran dan gaya belajar terhadap keterampilan berpikir kritis peserta didik kelas XI IPA SMA Negeri 3 Palopo pada materi pokok larutan asam basa. Jenis penelitian adalah eksperimen semu dengan menggunakan desain Faktorial 2x3. Populasi penelitian adalah seluruh peserta didik kelas XI IPA SMA Negeri 3 Palopo tahun ajaran 2013/2014 yang berjumlah 180 orang. Pengambilan sampel dilakukan dengan simple random sampling dan kelas yang terpilih adalah kelas XI IPA D dan XI IPA F. Pengujian hipotesis dilakukan dengan program SPSS 20 menggunakan analisis ANACOVA. Hasil penelitian ini menunjukkan bahwa (1) Ada pengaruh model pembelajaran terhadap keterampilan berpikir kritis peserta didik di kelas XI IPA SMA Negeri 3 palopo pada materi pokok larutan asam basa, (2) Tidak ada pengaruh gaya belajar visual, auditorial dan kinestetik terhadap keterampilan berpikir kritis peserta didik di kelas XI IPA SMA Negeri 3 palopo pada materi pokok larutan asam basa, (3) Tidak ada interaksi antara model pembelajaran dengan gaya belajar dalam mempengaruhi keterampilan berpikir kritis peserta didik kelas XI IPA SMA Negeri 3 Palopo pada materi larutan asam basa. Rata-rata keterampilan berpikir kritis peserta didik yang diajar dengan menggunakan model pembelajaran inkuiri lebih tinggi dari pada yang diajar dengan menggunakan model pembelajaran langsung. Ratarata keterampilan berpikir kritis peserta didik yang memiliki gaya belajar audiotori lebih tinggi dari pada peserta didik yang memiliki gaya belajar visual dan kinestetik.
\end{abstract}

Kata kunci: Model pembelajaran, Gaya belajar, Keterampilan berpikir kritis 


\begin{abstract}
This research aims to identify the influence of instructional model and learning style to critical thinking skills of students in class XI Science SMAN 3 Palopo in the subject matter acid-base solution. This type of research is quasi-experimental using factorial design $2 \times 3$. Population of the research was all students in class XI Science SMAN 3 Palopo school year 2013/2014 which amounted to 180 students. The sample was taken by simple random sampling and the selected class is XI D Science and XI F Science. The Hypothesis test was conducted by SPSS 20 Program using The ANACOVA (Analysis of Covariance) analysis. The results of this study show that (1) There is an influence of instructional model to critical thinking skills of students in class XI Science at SMAN 3 Palopo in the subject matter acid-base solution, (2) There is no influence of visual learning style, auditory and kinesthetic toward the critical thinking skills of students in class XI Science SMAN 3 Palopo in the subject matter acid-base solution, (3) There is no interaction between the instructional model and learning styles in influencing the critical thinking skills of students in class XI Science SMAN 3 Palopo the acid base solution material. Average critical thinking skills that students taught using inquiry learning model is higher than those taught using direct instructional model. Average score critical thinking skills of learners who have learning styles auditory higher than the learners who have visual and kinesthetic learning styles.
\end{abstract}

Keywords: Instructional model, Learning style, Critical thinking skills

\title{
PENDAHULUAN
}

Salah satu masalah yang
dihadapi dunia pendidikan adalah
lemahnya kualitas
pembelajaran. Pada umumnya proses
pembelajaran masih didominasi oleh
guru dan peserta didik kurang
didorong untuk mengembangkan
kemampuan berpikirnya. Proses
pembelajaran di dalam kelas diarahkan
kepada kemampuan anak untuk
menghapal informasi tanpa dituntut
untuk memahami informasi yang
diingatnya untuk menghubungkannya
dengan kehidupan sehari-hari.
Akibatnya, ketika peserta didik lulus
dari sekolah, mereka pintar secara
teoritis, tetapi mereka miskin aplikasi.

Kenyataan ini berlaku untuk semua mata pelajaran, khususnya mata pelajaran kimia tidak dapat mengembangkan keterampilan peserta didik untuk berpikir kritis dan matematis, karena model pembelajaran yang digunakan di dalam kelas umumnya masih mengarahkan peserta didik untuk menjadi penghafal yang baik, sehingga keterampilan berpikir tidak digunakan secara baik dalam setiap proses pembelajaran di dalam kelas. Hal ini mengakibatkan peserta didik kesulitan ketika masalah yang diberikan berbeda dengan yang diajarkan karena keterampilan berpikir kritis mereka belum terlalu terlatih 
selama proses pembelajaran berlangsung.

Usaha pembaharuan dalam bidang pendidikan dan pembelajaran di semua tingkat pendidikan diantaranya adalah mengembangkan keterampilan berpikir tingkat tinggi. Hal ini bertujuan untuk meningkatkan keterampilan berpikir logis, rasional dan reflektif yang berfokus pada apa yang harus dipercaya dan apa yang harus dilakukan untuk membuat keputusan. Keterampilan berpikir tingkat tinggi akan memberikan dampak pada meningkatnya keterampilan siswa dalam memecahkan masalah (Fischer, 2008).

Berdasarkan hasil observasi penulis di SMA Negeri 3 Palopo ditemukan bahwa keterampilan peserta didik untuk memecahkan masalah yang mereka temui dalam pelajaran kimia masih rendah. Untuk mengatasi hal tersebut, maka penulis memandang perlu diterapkan suatu model pembelajaran yang dapat melatih keterampilan berpikir kritis peserta didik dalam menyelesaikan masalah, baik yang mereka temui dalam pelajaran kimia maupun dalam kehidupan sehari-hari. Dengan demikian ketika peserta didik sudah mampu berpikir kritis, maka disisi lain dapat pula meningkatkan hasil belajar peserta didik.

Terdapat beberapa model yang dapat digunakan dalam pembelajaran yang dapat membantu peserta didik agar mampu berpikir kritis salah satunya adalah model pembelajaran inkuiri. Dari hasil observasi di SMA Negeri 3 Palopo permasalahan yang muncul adalah model pembelajaran inkuiri yang menekankan pada proses berpikir kritis belum sepenuhnya dapat diterapkan oleh guru-guru di SMA Negeri 3 Palopo karena adanya anggapan bahwa model pembelajaran inkuiri sebagai model pembelajaran yang sulit untuk diterapkan.

Selain model pembelajaran inkuiri, juga terdapat model pembelajaran langsung. Berbeda dengan model pembelajaran inkuiri, model pembelajaran langsung telah digunakan oleh guru-guru di sekolah. Model pembelajaran langsung merupakan salah satu model pembelajaran yang berpusat pada guru (Teacher-Center), berbeda dengan model pembelajaran inkuiri yang bersifat Student-Center. Meskipun model pembelajaran langsung berpusat pada guru, bukan berarti model pembelajaran ini tidak dapat mengaktifkan peserta didik. Dengan adanya model pembelajaran langsung seorang guru dapat mendesain pembelajaran sehingga peserta didik juga dapat ikut aktif dalam proses pembelajaran, misalnya dengan melakukan interaksi berupa tanya jawab atau pemberian resitasi selama proses pembelajaran berlangsung.

Selain model pembelajaran, salah satu faktor yang tak kalah pentingnya dalam menentukan hasil belajar peserta didik adalah gaya belajar peserta didik. Gaya belajar merupakan salah satu variabel kondisi belajar yang menjadi bahan pertimbangan dalam merancang pembelajaran. Pengetahuan tentang gaya belajar dalam pembelajaran dibutuhkan untuk merancang atau memodifikasi materi dan model 
pembelajaran. Diharapkan dengan adanya interaksi dari faktor gaya belajar dan model pembelajaran, hasil belajar peserta didik dapat dicapai secara maksimal. Gaya belajar menunjukkan cara tercepat dan terbaik bagi setiap individu untuk dapat menyerap informasi dari luar dirinya. Ada tiga gaya belajar seseorang yaitu : gaya belajar visual, audiotori dan kinestetik (Russel, 2011).

Materi larutan asam basa merupakan salah satu materi kimia kelas XI yang memadukan antara tingkat pemahaman konsep dan keterampilan berpikir kritis peserta didik dalam menyelesaikan materimateri baik materi perhitungan maupun teori. Dalam mengajarkan materi larutan asam basa, dapat digunakan beberapa model pembelajaran seperti inkuiri maupun langsung. Kedua model pembelajaran ini diharapkan dapat membantu peserta didik agar mampu mengembangkan keterampilan berpikir kritisnya dalam menyelesaikan masalah-masalah yang ditemukan dalam materi larutan asam basa ini. Peneliti kemudian tertarik untuk melakukan penelitian tentang pengaruh model pembelajaran dan gaya belajar terhadap keterampilan berpikir kritis peserta didik.

\section{METODE PENELITIAN}

Penelitian ini merupakan penelitian eksperimen semu (quasy eksperiment) yang bertujuan untuk melihat pengaruh dari model pembelajaran dan gaya belajar terhadap keterampilan berpikir kritis peserta didik kelas XI IPA SMA Negeri 3 Palopo pada materi larutan asam basa. Desain penelitian ini adalah desain faktorial yang dikategorikan sebagai desain faktorial 2 x 3 karena desain faktorial ini menggunakan variabel bebas manipulatif yang dibagi dua dan variabel bebas atributif yang dibagi menjadi tiga kelompok. Desain faktorial 2 x 3 yang digunakan, seperti Tabel 1.

Rumusan masalah penelitian yang dirumuskan sebagai berikut:

1. Apakah terdapat perbedaan keterampilan berpikir kritis antara peserta didik yang diajar dengan menggunakan model pembelajaran inkuiri dengan model pembelajaran langsung?

2. Apakah terdapat perbedaan keterampilan berpikir kritis antara peserta didik yang memiliki gaya belajar visual, audiotori dan kinestetik?

3. Apakah terdapat perbedaan selisih keterampilan berpikir kritis peserta didik yang memiliki gaya belajar visual, audiotori dan kinestetik pada model pembelajaran inkuiri dengan keterampilan berpikir kritis peserta didik yang memiliki gaya belajar visual, audiotori dan kinestetik pada pembelajaran langsung? 
Tabel 1. Desain Faktorial 2 x 3

\begin{tabular}{l|cc|c|}
\hline $\begin{array}{l}\text { Model Gaya Belajar } \\
\text { Pembelajaran }\end{array}$ & $\begin{array}{c}\text { Visual } \\
\left(\mathbf{B}_{\mathbf{1}}\right)\end{array}$ & $\begin{array}{c}\text { Auditorial } \\
\left(\mathbf{B}_{2}\right)\end{array}$ & $\begin{array}{c}\text { Kinestetik } \\
\left(\mathbf{B}_{3}\right)\end{array}$ \\
\hline $\begin{array}{l}\text { Model pembelajaran inkuiri }\left(\mathrm{A}_{1}\right) \\
\begin{array}{l}\text { Model pembelajaran } \\
\text { Langsung }\left(\mathrm{A}_{2}\right)\end{array}\end{array} \mathrm{A}_{1} \mathrm{~B}_{1}$ & $\mathrm{~A}_{1} \mathrm{~B}_{2}$ & $\mathrm{~A}_{1} \mathrm{~B}_{3}$ \\
\hline
\end{tabular}

Populasi dalam penelitian ini adalah seluruh peserta didik kelas XI IPA SMA Negeri 3 Palopo yang terdiri dari 6 kelas. Penentuan sampel dalam penelitian ini dilakukan dengan sistem simple random sampling dan terpilih dua kelas yakni kelas XI IPA D (kelas eksperimen 1) dan kelas XI IPA F (kelas eksperimen 2). Variabel pada penelitian terdiri dari dua variabel, yaitu variabel bebas dan variabel terikat. Ada 2 variabel bebas dalam penelitian ini yaitu variabel bebas manipulatif (model pembelajaran) dan variabel bebas atributif (gaya belajar). Sedangkan varibel terikatnya adalah keterampilan berpikir kritis.

Uji prasyarat analisis dilakukan uji normalitas dan homogenitas dengan bantuan program SPSS 20. Pengujian normalitas menggunakan analisis One Sample Kolmogorov Smirnov Test. Dengan kriteria pengujian: apabila signifikansi $(p)$ yang diperoleh lebih besar dari $\alpha=0,05$ maka data tersebut berasal dari populasi yang terdistribusi normal. Pengujian homogenitas dihitung dengan bantuan program SPSS 20 menggunakan analisis Levene Statistic. Dengan kriteria pengujian: apabila signifikansi $(p)$ yang diperoleh lebih besar dari $\alpha=0,05$ maka data tersebut berasal dari populasi yang homogen. Analisis statistik inferensial digunakan untuk menguji kebenaran hipotesis yang diajukan. Pengujian hipotesisi diuji dengan bantuan program SPSS 20 menggunakan analisis ANACOVA (Analisis Of Covariance) dengan kriteria pengujian: terima $\mathrm{H}_{0}$ jika ( $p$ ) yang diperoleh lebih besar dari $\alpha=0,05$ maka data tersebut berasal dari populasi yang homogen.

\section{HASIL DAN PEMBAHASAN}

\section{A. Hasil Penelitian}

Analisis statistik deskriptif mengenai keterampilan berpikir kritis peserta didik yang diajar dengan menggunakan model pembelajaran inkuiri dan model pembelajaran langsung didalamnya mencakup mean, median, modus, nilai maximum dan nilai minimum. Hasil analisis statistik disajikan pada Tabel 2. 
Tabel 2. Deskripsi Keterampilan Berpikir Kritis Peserta Didik yang diajar dengan Model Pembelajaran Inkuiri dan Model Pembelajaran Langsung

\begin{tabular}{lcccc}
\hline \multirow{2}{*}{ Statistik } & \multicolumn{2}{c}{ Kelas Inkuiri } & \multicolumn{2}{c}{ Kelas Langsung } \\
\cline { 2 - 5 } & Pretest & Posttest & Pretest & Postest \\
\hline $\mathrm{N}$ & 30 & 30 & 30 & 30 \\
Mean & 23.32 & 61.81 & 24.45 & 56.71 \\
Median & 24.00 & 66.80 & 26.00 & 59.20 \\
Modus & 24.80 & 68.00 & 27.20 & 58.40 \\
Std. deviasi & 3.05 & 12.26 & 7.86 & 9.50 \\
Varians & 9.34 & 150.37 & 61.78 & 90.32 \\
Range & 12.80 & 47.20 & 24.80 & 35.20 \\
Nilai Minimum & 17.60 & 37.60 & 12.80 & 33.60 \\
Nilai maximum & 30.40 & 84.80 & 37.60 & 68.80 \\
\hline
\end{tabular}

Tabel 3 mendeskripsikan tentang keterampilan berpikir kritis peserta didik pada setiap kelas eksperimen menunjukkan bahwa nilai rata-rata pretest peserta didik yang diajar dengan menggunakan model pembelajaran inkuiri $(23,33)$ lebih rendah jika dibandingkan dengan nilai rata-rata pretest peserta didik yang diajar mengunakan model pembelajaran langsung $(24,45)$. Untuk nilai posttest, rata-rata nilai posttest peserta didik yang diajar dengan menggunakan model pembelajaran inkuiri $(61,81)$ lebih tinggi dibandingkan dengan nilai peserta didik yang diajar dengan menggunakan model pembelajaran langsung (56,71). Artinya model pembelajaran inkuiri lebih baik dibandingkan dengan model pembelajaran langsung dalam mempengaruhi keterampilan berpikir kritis peserta didik. Deskripsi keterampilan berpikir kritis peserta didik berdasarkan gaya belajar ditunjukkan pada Tabel 3.

Tabel 3. Deskripsi Keterampilan Berpikir Kritis Peserta Didik berdasarkan Gaya Belajar (Visual, Audiotori dan Kinestetik) dan Model Pembelajaran

\begin{tabular}{|c|c|c|c|c|c|}
\hline Gaya Belajar & Statistik & $\begin{array}{c}\text { Visual } \\
\left(B_{1}\right)\end{array}$ & $\begin{array}{l}\text { Audiotori } \\
\qquad\left(\mathbf{B}_{2}\right)\end{array}$ & $\begin{array}{c}\text { Kinestetik } \\
\left(\mathbf{B}_{\mathbf{3}}\right)\end{array}$ & Total \\
\hline \multirow{3}{*}{ Inkuiri $\left(\mathrm{A}_{1}\right)$} & $\mathrm{N}$ & 15 & 7 & 8 & 30 \\
\hline & Mean & 56.96 & 69.14 & 64.50 & 63.53 \\
\hline & Std. deviasi & 12.22 & 13.37 & 7.63 & 11.07 \\
\hline \multirow[t]{2}{*}{ Langsung $\left(\mathrm{A}_{2}\right)$} & $\mathrm{N}$ & 15 & 10 & 5 & 30 \\
\hline & Mean & 56.68 & 55.76 & 58.72 & 57.05 \\
\hline
\end{tabular}




\begin{tabular}{llcccc}
\hline & & & & & \\
& Std. deviasi & 9.52 & 11.26 & 6.68 & 9.15 \\
\hline Total & N & 30 & 17 & 13 & \\
& Mean & $\mathbf{5 6 . 8 2}$ & $\mathbf{6 1 . 4 5}$ & $\mathbf{6 1 . 6 1}$ & \\
& Std. deviasi & 10.87 & 12.315 & 7.155 & \\
\hline
\end{tabular}

Berdasarkan Tabel 3 terlihat nilai rata-rata yang mendeskripsikan keterampilan berpikir kritis peserta didik ditinjau dari segi gaya belajarnya, yakni gaya belajar visual, audiotori dan kinestetik. Dari tabel 3 terlihat bahwa nilai rata-rata keterampilan berpikir kritis peserta didik yang memiliki gaya belajar audiotori $(69,14)$ lebih tinggi dibanding nilai rata-rata keterampilan berpikir kritis peserta didik yang memiliki gaya belajar visual $(56,96)$ dan kinestetik $(64,50)$ pada kelas yang diajar dengan model pembelajaran inkuiri. Pada kelas yang diajar dengan menggunakan model pembelajaran langsung terlihat bahwa nilai rata-rata keterampilan berpikir kritis peserta didik yang memiliki gaya belajar kinestetik $(58,72)$ lebih besar dibandingkan dengan peserta didik yang memiliki gaya belajar visual $(56,68)$ dan audiotori $(58,72)$. $\begin{array}{lcr}\text { Tabel } & 4 & \text { memberikan } \\ \text { gambaran } & \text { mengenai } & \text { kategori }\end{array}$ keterampilan berpikir kritis peserta didik yang diajar dengan menggunakan model pembelajaran inkuiri dan model pembelajaran langsung.Peserta didik yang diajar dengan menggunakan model pembelajaran inkuiri yang berada pada kategori sangat tinggi 1 orang, tinggi 18 orang, sedang 10 orang dan rendah 1 orang. Sedangkan peserta yang diajar dengan menggunakan model pembelajaran langsung yang berada pada kategori tinggi 14 orang, sedang 13 orang dan rendah 3 orang. Rata-rata peserta didik yang diajar dengan menggunakan model pembelajaran inkuiri berada pada kategori tinggi, sedangkan untuk peserta didik yang diajar dengan menggunakan model pembelajaran langsung berada pada kategori sedang.

Tabel 4. Kategori Keterampilan Berpikir Kritis Peserta Didik

\begin{tabular}{ccc}
\hline \multirow{2}{*}{ Kategori } & \multicolumn{2}{c}{ Model Pembelajaran } \\
\cline { 2 - 3 } & Inkuiri & Langsung \\
\hline Sangat Tinggi & 1 & 0 \\
Tinggi & 18 & 14 \\
Sedang & 10 & 13 \\
Rendah & 1 & 3 \\
Sangat Rendah & 0 & 0 \\
\hline
\end{tabular}


Berdasarkan hasil pengujian hipotesis dilakukan dengan bantuan SPSS 20 dengan menggunakan analisis ANACOVA (Analysis Of Covarianve). Hasil pengujian hipotesis merupakan jawaban dari masalah 1,2 dan 3 . Adapun hasil pengujian hipotesis sebagai berikut:

\section{Hipotesis I}

Hasil análisis menunjukkan bahwa signifikansi lebih kecil dari $\alpha=$ 0,05 berarti Ho ditolak dan $\mathrm{H}_{1}$ diterima, yang berarti benar terdapat perbedaan keterampilan berpikir kritis peserta didik yang diajar dengan menggunakan model pembelajaran inkuiri dengan peserta didik yang diajar dengan menggunakan model pembelajaran langsung khususnya pada materi pokok larutan asam basa kelas XI IPA SMA Negeri 3 Palopo.

\section{Hipotesis II}

Hasil pengujian menunjukkan bahwa signifikansi lebih besar dari $\alpha=$ 0,05 sehingga $\mathrm{Ho}$ diterima dan $\mathrm{H}_{1}$ ditolak.Artinya, tidak terdapat perbedaan keterampilan berpikir kritis peserta didik yang memiliki gaya belajar visual, audiotori dan kinestetik khususnya pada materi larutan asam dan basa yang diajarkan pada kelas XI IPA SMA Negeri 3 Palopo.

\section{Hipotesis III}

Hasil analisis menunjukkan bahwa signifikansi lebih besar dari $\alpha=$ 0,05 sehingga Ho gagal ditolak artinya tidak terdapat perbedaan selisih ratarata kelompok yang memiliki gaya belajar visual, audiotori dan kinestetik yang diajar dengan menggunakan model pembelajaran inkuiri dan model pembelajaran langsung. Oleh karena hasil pengujian hipótesis menunjukkan bahwa tidak terdapat selisih antara model pembelajaran dan gaya belajar maka tidak dilakukan uji lanjut Post Hoc Tuckey HSD.

\section{B. Pembahasan}

Penelitian ini bertujuan untuk mengetahui pengaruh model pembelajaran dan gaya belajar terhadap keterampilan berpikir kritis peserta didik kelas XI IPA SMA Negeri 3 palopo. Berdasarkan pada rumusan masalah (1,2 dan 3) bahwa pengaruh perlakuan terhadap keterampilan berpikir kritis secara operasional dapat dilihat dari perbedaan keterampilan berpikir kritis peserta didik dari kelompok yang dibandingkan. Sehingga dalam pembahasan ini perbedaan-perbedaan tersebut akan dikembalikan kepengertian pengaruh. Dalam artian bahwa jika ada perbedaan maka ada pengaruh.

\begin{tabular}{lrrr}
\multicolumn{2}{c}{ Berdasarkan pada } & Hasil \\
analisis & statistik & deskriptif
\end{tabular} menunjukkan bahwa nilai rata-rata keterampilan berpikir kritis peserta didik yang diajar dengan menggunakan model pembelajaran inkuiri lebih tinggi dari pada rata-rata nilai peserta didik yang diajar dengan menggunakan model pembelajaran langsung. Hal ini menunjukkan bahwa model pembelajaran inkuiri lebih baik dibandingkan dengan model pembelajaran langsung.

$$
\text { Hasil analisis statistik }
$$
inferensial adanya perbedaan antara keterampilan berpikir kritis peserta 
didik yang diajar dengan menggunakan model pembelajaran inkuiri dan model pembelajaran langsung menunjukkan bahwa ada pengaruh dari model pembelajaran terhadap keterampilan berpikir kritis peserta didik. Pembelajaran inkuiri sebagian besar melibatkan kemampuan peserta didik secara aktif dalam menemukan konsep-konsep dan prinsip-prinsip. Hasil penelitian Miftah (2013) Menunjukkan bahwa secara keseluruhan rata-rata skor keterampilan berpikir kritis berada pada kategori tinggi untuk peserta didik yang diajar dengan menggunakan model pembelajaran inkuiri.

$\begin{array}{ccc}\text { Berbeda } & \text { dengan } & \text { model } \\ \text { pembelajaran } & \text { inkuiri, } & \text { model }\end{array}$ pembelajaran langsung merupakan salah satu model pembelajaran yang berpusat pada guru. Tiap tahapan dalam pembelajaran ini secara garis besar didominasi oleh guru. Model pembelajaran langsung ini diajarkan dengan menyampaikan materi pembelajaran setahap demi setahap. Hal ini bertujuan untuk membantu peserta didik dalam mengkonstruk pengetahuannya. Penyampaian materi pembelajaran dengan menggunakan model langsungyang dominan menggunakan metode ceramah dapat menjadi pemicu munculnya kebosanan dalam diri peserta didik, sehingga secara tidak langsung dapat berdampak kepada motivasi belajar peserta didik. Kurangnya motivasi peserta didik dalam menyelesaikan masalah yang diajukan oleh guru berdampak juga pada rendahnya keterampilan berpikir kritis peserta didik.
Melihat nilai rata-rata dari ketrampilan berpikir kritis peserta didik kelas yang diajar dengan menggunakan model pembelajaran inkuiri maupun langsung untuk peserta didik yang memiliki gaya belajar visual nilai rata-ratanya hampir sama yakni 56,96 dan 56,68. Secara keseluruhan rata-rata nilai keterampilan berpikir kritis peserta didik yang memiliki gaya belajar visual, auditori dan kinestetik hampir sama besar, sehingga gaya belajar tidak secara signifikan mempengaruhi keterampilan berpikir kritis peserta didik. Tidak adanya pengaruh dari gaya belajar juga dapat dilihat pada ketuntasan tiap peserta didik, untuk kelas yang diajar dengan menggunakan model pembelajaran inkuiri hanya 1 orang peserta didik yang memiliki gaya belajar audiotori yang tuntas sedangkan untuk kelas langsung tidak ada yang tuntas. Penentuan gaya belajar peserta didik menjadi salah satu kelamahan dalam penelitian ini, karena hampir semua peserta didik dalam penelitian ini memiliki ketiga gaya belajar visual, audiotori dan kinestetik sehingga tidak ada gaya belajar peserta didik yang dominan.

Pada penelitian ini juga terlihat antara model pembelajaran dan gaya belajar peserta didik tidak saling mempengaruhi. Dengan demikian tidak ada konstribusi secara bersamasama yang yang dapat disumbangkan antara model dengan gaya belajar untuk meningkatkan keterampilan berpikir kritis peserta didik. 


\section{KESIMPULAN DAN SARAN}

\section{A. Kesimpulan}

Berdasarkan pada hasil penelitian dan pembahasan, maka dapat ditarik kesimpulan sebagai berikut: (1) Ada pengaruh model pembelajaran terhadap keterampilan berpikir kritis peserta didik di kelas XI IPA SMA Negeri 3 palopo pada materi pokok larutan asam dan basa, (2) Tidak ada pengaruh gaya belajar visual, auditorial dan kinestetik terhadap keterampilan berpikir kritis peserta didik di kelas XI IPA SMA Negeri 3 palopo pada materi pokok larutan asam dan basa dan (3) Tidak ada interaksi antara model pembelajaran dan gaya belajar dalam mempengaruhi keterampilan berpikir kritisi peserta didik kelas XI IPA SMA Negeri 3 Palopo pada materi pokok larutan asam dan basa.

\section{B. Saran}

Berdasarkan pada hasil penelitian yang diperoleh dalam penelitian ini, maka disarankan: (1) Guru hendaknya mempertimbangkan model pembelajaran sebagai salah satu alternatif dalam pembelajaran kimia sehingga peserta didik dapat mencapai hasil belajar yang optimal sesuai dengan tujuan pembelajaran, (2) Guru diharapkan dapat menggunakan model pembelajaran inkuiri dalam mengajarkan materi larutan asam basa dan (3) Guna penelitian lanjutan, jika peneliti ingin melihat pengaruh dari gaya belajar (Visual, Audiotori dan Kinestetik) diharapkan untuk menggunakan instrument tes gaya belajar yang lebih baik dibandingkan instrument tes yang digunakan dalam penelitian ini.

\section{DAFTAR PUSTAKA}

Fischer, Alec. 2008. BerpikirKritis (Sebuah Pengantar). Jakarta: Erlangga.

Miftah. 2013. Pengembangan perangkat pembelajaran berorientasi metode penemuan terbimbing dalam pencapaian proses sains dan keterampilan berpikir kritis peserta didik MAN 2 Model Makassar. Thesis. Tidak diterbitkan . PPs UNM: Makassar

Russel. 2011. Accelereated Learning Field Book, Panduan Belajar Cepat di Dunia yang Padat. Bandung :Nusamedia 